\title{
Effects of Confining Stress on the Post-Peak Behaviour and Fracture Angle of Fauske Marble and Iddefjord Granite
}

\author{
Huijian Zhang ${ }^{1,2} \cdot$ Charlie C. Li ${ }^{2}$
}

Received: 7 August 2018 / Accepted: 5 December 2018 / Published online: 24 December 2018

(c) The Author(s) 2018

Keywords Post-peak behaviour $\cdot$ Fracture angle $\cdot$ Triaxial compression test $\cdot$ Shear rupture $\cdot$ Rock damage $\cdot$ Strain burst

\section{List of Symbols}

$\begin{array}{ll}\sigma_{1} & \text { Axial stress } \\ \sigma_{3}\left(=\sigma_{2}\right) & \text { Confining stress } \\ \mathrm{S} & \text { Differential stress }\left(\sigma_{1}-\sigma_{3}\right) \\ S_{\mathrm{p}} & \text { Ultimate differential stress } \\ \beta & \text { Fracture angle } \\ \beta_{0} & \text { Fracture angle of the rock specimen under } \\ & \text { uniaxial loading } \\ \mathrm{a} & \text { Material constant } \\ \mathrm{DI} & \text { Damage Index } \\ V_{0} & \text { Intrinsic ejection velocity of rock } \\ W_{\mathrm{a}} & \text { Excess energy (or released energy) for Class II } \\ & \text { rock } \\ W_{\mathrm{e}} & \text { Elastic energy at the onset of faulting for Class } \\ & \text { I rock } \\ W_{\mathrm{r}} & \text { Fracture energy at the onset of faulting for } \\ & \text { Class I rock } \\ W_{\mathrm{r} 0} & \text { Total fracture energy (or input energy) under } \\ & \text { uniaxial loading for Class I rock }\end{array}$

\section{Introduction}

In general, the strength of rock and rock mass is non-linearly associated with the confining stress. Thus, the non-linear Hoek-Brown strength criterion (Hoek and Brown 1980, 1982 ) is more appropriate than the linear Mohr-Coulomb criterion for rock and rock mass. Shear failure usually

Charlie C. Li

charlie.c.li@ntnu.no

1 Key Laboratory of Transportation Tunnel Engineering, Ministry of Education, School of Civil Engineering, Southwest Jiaotong University, Chengdu 610031, China

2 Department of Geoscience and Petroleum, Norwegian University of Science and Technology (NTNU),

7491 Trondheim, Norway dominates in the process of rock failure even though extensional fracturing occurs in the early stage of the loading under unconfined uniaxial compression. The non-linearity in strength implies that the angle of the shear rupture plane changes with the confining stress. This phenomenon has been observed by others, for example, Mogi (1966, 1971), Wawersik and Fairhurst (1970), Paterson (1978), Bésuelle et al. (2000), Alejano et al. (2009) and Tarasov and Potvin (2013), but the physical mechanism behind the phenomenon needs to be further studied.

It is also known that the confining stress changes the postpeak mechanical behaviour of the rock. It is experimentally demonstrated that the rock becomes more ductile in the postpeak stage with an increase in the confining stress (Wawersik and Fairhurst 1970; Gowd and Rummel 1980; Scott and Nielsen 1991; Yang et al. 2012; Ai et al. 2016; Yao et al. 2016; Walton et al. 2015). However, there is not a method for quantitatively measuring the influence of the confining stress to the plasticity of the rock in the post-peak stage.

This study aims at the relationships of the post-peak stress-strain behaviour and the fracture angle of rock with the fracturing state of the rock. Two types of rocks, specimens of Fauske marble and Iddefjord granite, were used for the study. The Fauske marble is a typical Class I rock, while the Iddefjord granite is a Class II rock. The cylindrical specimens were tested on a servo-controlled rock testing machine with the confining stress varying from 0 to $120 \mathrm{MPa}$ for the marble specimens but to $85 \mathrm{MPa}$ for the granite specimens. A Damage Index (DI) is proposed to describe the damage degree of the rock in the post-peak stage for Class I rock. An intrinsic ejection velocity is proposed to describe the potential of strain burst that is purely determined by the strain energy released from Class II rock. A quantitative relationship between the fracture angle and the confining stress is established for rock. 


\section{Experimental Apparatus and Procedure}

\subsection{Experimental Apparatus}

All the tests were performed on the servo-controlled stiff testing machine, GCTS RTR-4000, which has an axial load capacity of $4000 \mathrm{kN}$ and a frame stiffness of $15 \mathrm{GN} / \mathrm{m}$ (Tkalich et al. 2016). The triaxial pressure cell equipped on the testing machine has a capacity of $140 \mathrm{MPa}$ for the confining stress. The axial and radial strains of the rock specimen were measured with linear variable differential transformers (LVDTs). The axial strain is measured between two steel rings, axially spaced for $92.1 \mathrm{~mm}$, mounted on the specimen. The radial strain is measured with a circumferential LVDT.

\subsection{Specimens}

The marble and the granite in the study were, respectively, from Fauske and Iddefjord, Norway. They were tailored into cylindrical rock specimens in accordance with the ISRM suggested method for compression tests (Franklin 2007). The nominal dimensions of the specimens were $53 \mathrm{~mm}$ in diameter and $137 \mathrm{~mm}$ in length with a length-to-diameter ratio of approximately 2.5 .

\subsection{Experiment procedures}

The marble specimens were tested under six confining stresses, $0,10,30,55,85$ and $120 \mathrm{MPa}$, with three specimens tested under each confining stress. The first step of the test is to apply a hydrostatic pressure on the rock specimen until the pressure reaches the required magnitude of the confining stress. After that, the axial stress is increased while keeping the confining stress constant. The loading rate of the axial stress is adjusted to approximately $0.8 \mathrm{MPa} / \mathrm{s}$ and the loading is switched to axial strain control at a rate of approximately $15 \times 10^{-6} / \mathrm{s}$ when the load level is close to the peak strength. The axial strain rate is gradually increased with the increase in the axial strain in the post-peak stage. The maximum axial strain rate is $30 \times 10^{-6} / \mathrm{s}$.

The confining stresses for the granite specimens were 0 , $10,30,55$ and $85 \mathrm{MPa}$. The confining stress $120 \mathrm{MPa}$ was not used for the granite specimens because of the limitation of the loading capacity of the machine. For the granite specimens with confining stresses 0 and $10 \mathrm{MPa}$, the loading is under axial stress control at an axial stress rate of $0.8 \mathrm{MPa} / \mathrm{s}$ until $20 \mathrm{MPa}$. Then, it is switched to radial strain control at a radial strain rate of $-4.2 \times 10^{-6} / \mathrm{s}$. The radial strain rate is increased gradually to $-5 \times 10^{-6} / \mathrm{s}$ until the peak stress is reached. For specimens with confining stresses higher than $10 \mathrm{MPa}$, it is axial strain control at a strain rate of $20 \times 10^{-6} / \mathrm{s}$ until the axial stress is $100 \mathrm{MPa}$. After that, it is switched to radial strain control at a radial strain rate of $-4.2 \times 10^{-6} / \mathrm{s}$. In the post-peak stage, it is under radial strain control and the radial strain rate is manually increased so that the test can be finished within a reasonable time for all the granite specimens.

\section{Experimental results}

\subsection{Stress-strain curves}

Figure 1 presents the representative stress-strain curves of the marble and granite specimens at different confining stresses. The ultimate differential stresses of the specimens are summarized in Table 1. In this study, it is defined that the signs of compressive stress and strain are positive. The principal stresses are $\sigma_{1}$ in the axial direction and $\sigma_{2}=\sigma_{3}$ in the transverse directions. The differential stress is written as $S=\sigma_{1}-\sigma_{3}$ and the peak stress $S_{\mathrm{p}}$ is the ultimate differential stress.

\subsection{Fracture Angles}

A rock specimen usually fails along one or more than one fracture plane inclined to the major principal stress $\sigma_{1}$ applied on the specimen when $\sigma_{1}$ reaches its ultimate value, Fig. 2. The fracture angle $\beta$ is defined as the angle between the normal line to the fracture plane and the direction of $\sigma_{1}$ or between the fracture plane and the direction of $\sigma_{3}$, as shown in Fig. 2a.

Figure $2 b, c$ show the fracture angles measured on the representative marble and granite specimens tested under different confining stresses. The fracture angle decreased with the confining stress in both rock specimens. This result agrees with the observations in the tests of others (Mogi 1966; Bésuelle et al. 2000; Tarasov and Potvin 2013).

\section{Discussion}

\subsection{Effect of Confining Stress on the Post-Peak Behaviour}

\subsubsection{Marble specimens}

Figure 3 illustrates a typical differential stress-strain curve of a Class I rock in compression test. The curve becomes non-linear after the stress is beyond the yield point, namely the linear elastic portion ends. The stress either remains at the peak level or slowly descends after it reaches the peak. The stress descending suddenly accelerates after a certain amount of displacement and the stress finally stabilizes at the 
Fig. 1 Representative stressstrain curves: a marble specimens (M-US-2, M-TRX10-3, M-TRX30-2, M-TRX55-3, M-TRX85-1 and M-TRX120-1); b granite specimens (G-US2, G-TRX10-1, G-TRX30-1, G-TRX55-1, G-TRX85-1)
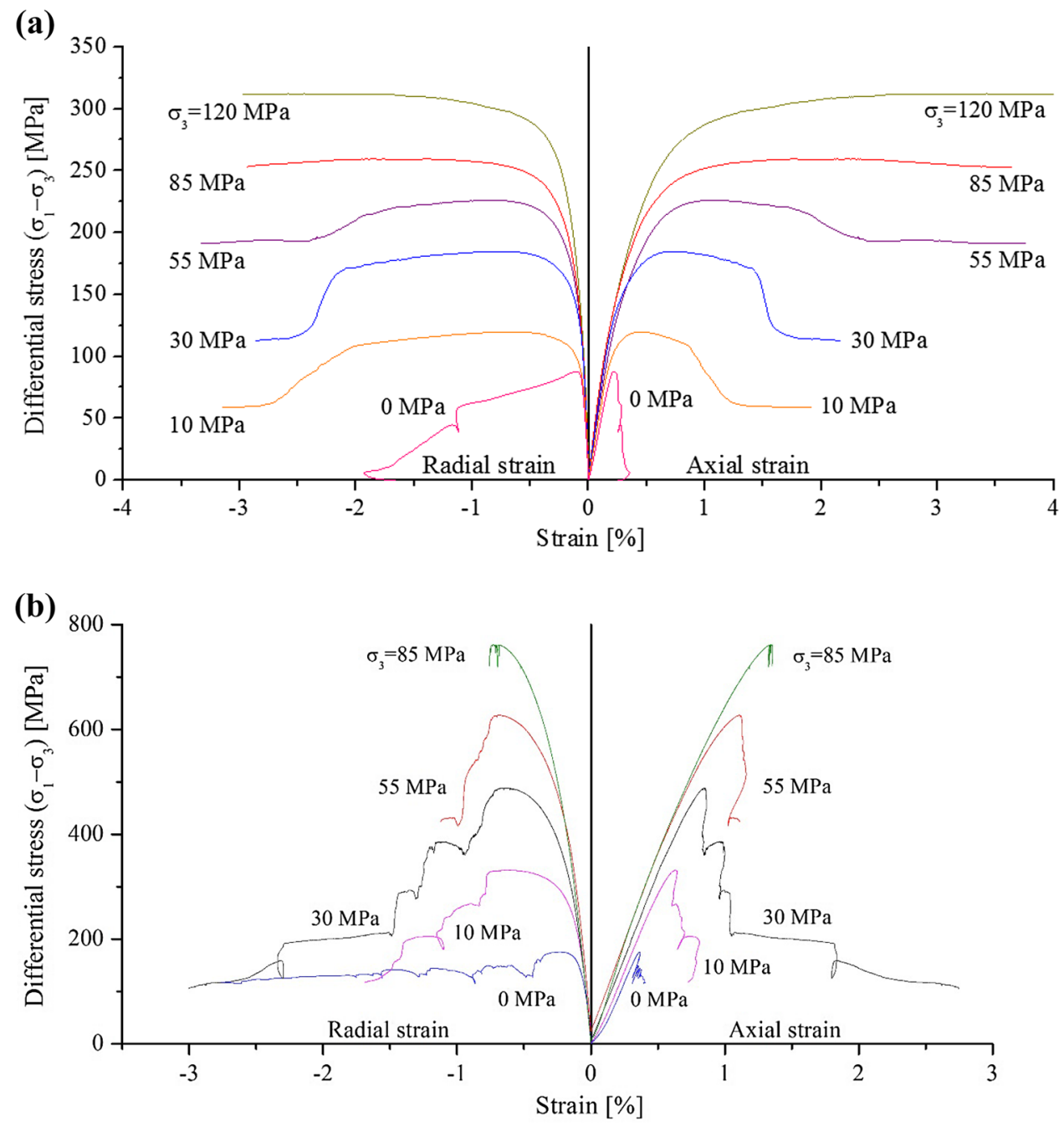

residual strength level. The start point of the stress descending acceleration is associated with the onset of the creation of the major shear rupture plane, or called the onset of faulting. The plastic deformation and micro fractures induced by stresses are uniformly distributed in the material until the onset of faulting. After that, micro fractures coalescence in a narrow band which develops to a major shear rupture plane to the end. At the residual strength level, no more fracturing would occur in the material except for frictional grinding along the rupture plane. The input energy during testing is used for damaging the rock and for elastically deforming the rock. In other words, the input energy is the sum of the fracture energy $W_{\mathrm{r}}$, dissipated for plastic deformation and rock fracturing, and the elastic energy $W_{\mathrm{e}}$, used for elastically deforming the rock, as illustrated in Fig. 3. The fracture energy is essentially a more appropriate parameter than the input energy to describe the damage degree of the rock material.

The fracturing of rock involves other energy parameters in addition to the elastic and fracture energies, as mentioned by Hauquin et al. (2018), Tarasov and Stacey (2017), Huang and $\mathrm{Li}$ (2014). However, the elastic and fracture energies are directly associated with the stress-strain characteristic of the rock and thus they are considered in this study.

It is seen in Fig. 1a that the residual strength is zero for the specimen tested under confining stress $0 \mathrm{MPa}$, implying that the input energy is entirely dissipated for the damage of the rock under the uniaxial compression. In general, more fracture energy is dissipated under triaxial compression than under uniaxial compression. In other words, the rock is more damaged in the post-peak stage under triaxial compression than under uniaxial compression. It is easier to figure out how different the damage generated under triaxial compression is from the damage under uniaxial compression by using a relative value instead of the absolute quantities of fracture energy. Therefore, a damage index is constructed below for this purpose:

$\mathrm{DI}=\frac{W_{\mathrm{r}}}{W_{\mathrm{r} 0}}$ 
Table 1 Test results of all the specimens

\begin{tabular}{|c|c|c|c|c|c|}
\hline Rock type & Specimen & $\sigma_{3}(\mathrm{MPa})$ & $S_{\mathrm{p}}(\mathrm{MPa})$ & Average $S_{\mathrm{p}}(\mathrm{MPa})$ & $\begin{array}{l}\text { Residual } \\
\text { strength } \\
\left(\sigma_{1 \mathrm{r}}{ }^{\mathrm{a}}-\sigma_{3}\right)(\mathrm{MPa})\end{array}$ \\
\hline \multirow[t]{18}{*}{ Marble } & M-US-1 & 0 & 93.6 & 93.2 & - \\
\hline & M-US-2 & 0 & 87.8 & & - \\
\hline & M-US-3 & 0 & 98.2 & & - \\
\hline & M-TRX10-1 & 10 & 132.4 & 128.3 & - \\
\hline & M-TRX10-2 & 10 & 132.5 & & 46.8 \\
\hline & M-TRX10-3 & 10 & 119.9 & & 59.2 \\
\hline & M-TRX30-1 & 30 & 166.2 & 178.3 & 119.8 \\
\hline & M-TRX30-2 & 30 & 184.6 & & 113.9 \\
\hline & M-TRX30-3 & 30 & 184.2 & & 116.2 \\
\hline & M-TRX55-1 & 55 & 215.0 & 224.0 & - \\
\hline & M-TRX55-2 & 55 & 231.0 & & - \\
\hline & M-TRX55-3 & 55 & 226.1 & & 191.2 \\
\hline & M-TRX85-1 & 85 & 259.5 & 257.6 & - \\
\hline & M-TRX85-2 & 85 & 264.5 & & - \\
\hline & M-TRX85-3 & 85 & 248.9 & & - \\
\hline & M-TRX120-1 & 120 & 312.3 & 297.9 & - \\
\hline & M-TRX120-2 & 120 & 285.0 & & - \\
\hline & M-TRX120-3 & 120 & 296.4 & & - \\
\hline \multirow[t]{9}{*}{ Granite } & G-US-1 & 0 & 179.4 & 177.2 & - \\
\hline & G-US-2 & 0 & 175.1 & & - \\
\hline & G-TRX10-1 & 10 & 331.4 & 331.5 & - \\
\hline & G-TRX10-2 & 10 & 331.6 & & - \\
\hline & G-TRX30-1 & 30 & 488.1 & 496.4 & - \\
\hline & G-TRX30-2 & 30 & 504.6 & & - \\
\hline & G-TRX55-1 & 55 & 627.3 & 635.9 & - \\
\hline & G-TRX55-2 & 55 & 644.5 & & - \\
\hline & G-TRX85-1 & 85 & 761.8 & 761.8 & - \\
\hline
\end{tabular}

${ }^{\mathrm{a}} \sigma_{1 \mathrm{r}}$ represents the residual axial stress where DI is the damage index expressing the relative damage extent with respect to the damage generated under uniaxial compression; $W_{\mathrm{r}}$ represents the fracture energy at a given axial strain under triaxial compression; and $W_{\mathrm{r} 0}$ the total fracture energy dissipated under uniaxial compression. This index can be used to describe the relative damage of a rock under any other loading condition, such under true-triaxial loading, as long as the fracture energy can be calculated on the stress-strain curves.

The onset of faulting did not show up on the stress-strain curves of the marble specimens that were tested under confining stresses 85 and $120 \mathrm{MPa}$ when the tests were terminated at the axial strain of approximately $4 \%$. In Table 2 , therefore, presented are only the fracture energies of the marble specimens tested under confining stresses 10, 30 and $55 \mathrm{MPa}$. The DI values of those specimens, calculated according to Eq. (1), are also presented in the table. The damage degrees in the specimens tested under confining stresses 10, 30 and $55 \mathrm{MPa}$ are 6,17 and 26 times the damage in the uniaxial tested specimen, respectively. The DI value increases approximately linearly with the confining stress.

\subsubsection{Granite specimens}

The Iddefjord granite exhibits Class II behaviour, as shown in Fig. 1b. A typical Class II rock behaves as depicted in Fig. 4 under the servo-controlled triaxial loading condition. The differential stress drops from the peak (point $\mathrm{P}$ ) to a lower level (point A) without any change in the axial strain. After that, the axial strain reverses with a decrease in the stress for an amount (until point B) and then turns to increase. Finally, the stress stabilizes at the level of the residual strength, which is equal to the frictional resistance on the shear rupture planes. One or more than one shear rupture planes are formed to the end. Based on the experimental results, it seems that the length of the vertical segment PA increases with the confining stress (Fig. 1b). 
(b)
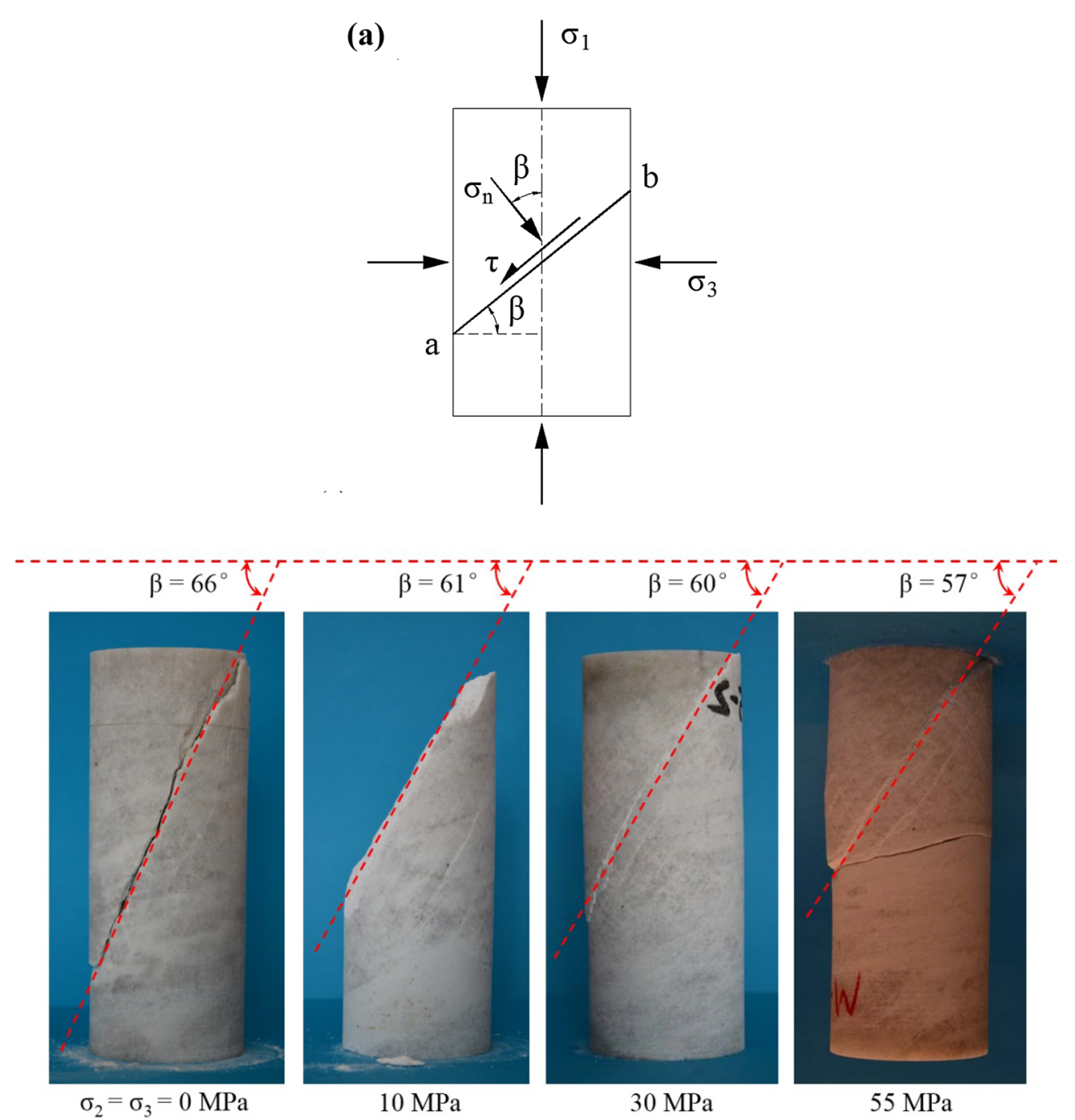

(c)

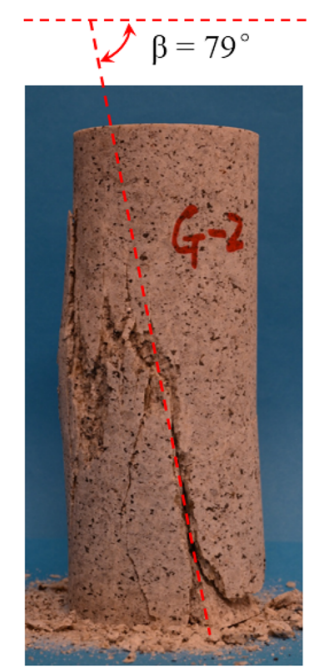

$\sigma_{2}=\sigma_{3}=0 \mathrm{MPa}$

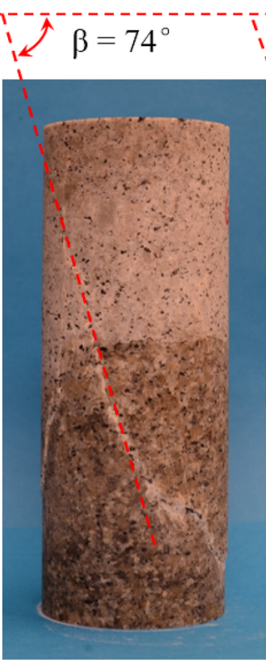

$10 \mathrm{MPa}$

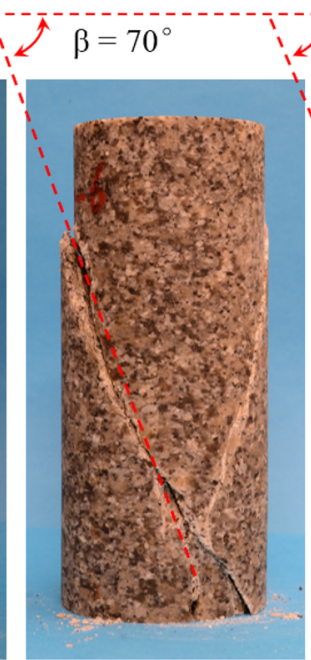

$30 \mathrm{MPa}$

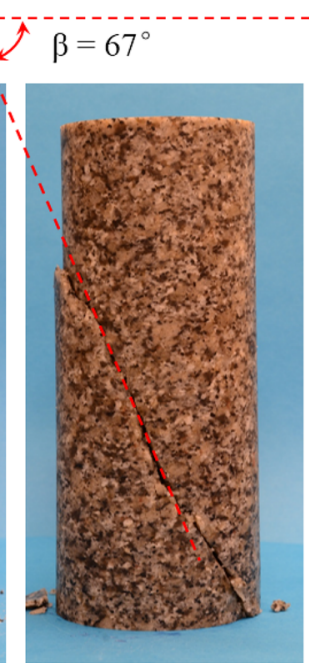

$55 \mathrm{MPa}$

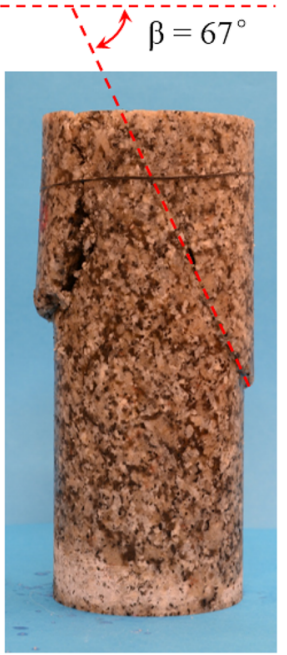

$85 \mathrm{MPa}$

Fig. 2 Fracture angles $\beta$ of specimens tested under different confining stresses: a definition of the $\beta$; $\mathbf{b}$ for marble; $\mathbf{c}$ for granite 


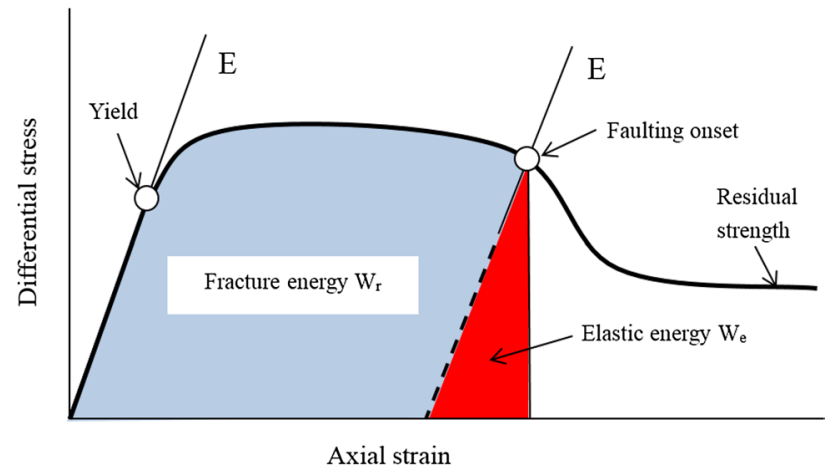

Fig. 3 Schematic stress-strain curve of Class I rock, illustrating the fracture and elastic energies in the rock specimen

Table 2 Fracture energies of the marble specimens and the DI values at the onset of faulting

\begin{tabular}{lcr}
\hline$\sigma_{3}(\mathrm{MPa})$ & $\begin{array}{l}\text { Fracture } \\
\text { energy } W_{\mathrm{r}} \\
(\mathrm{kJ})\end{array}$ & DI \\
\hline 0 & 122 & 1 \\
10 & 769 & 6 \\
30 & 2072 & 17 \\
55 & 3197 & 26 \\
\hline
\end{tabular}

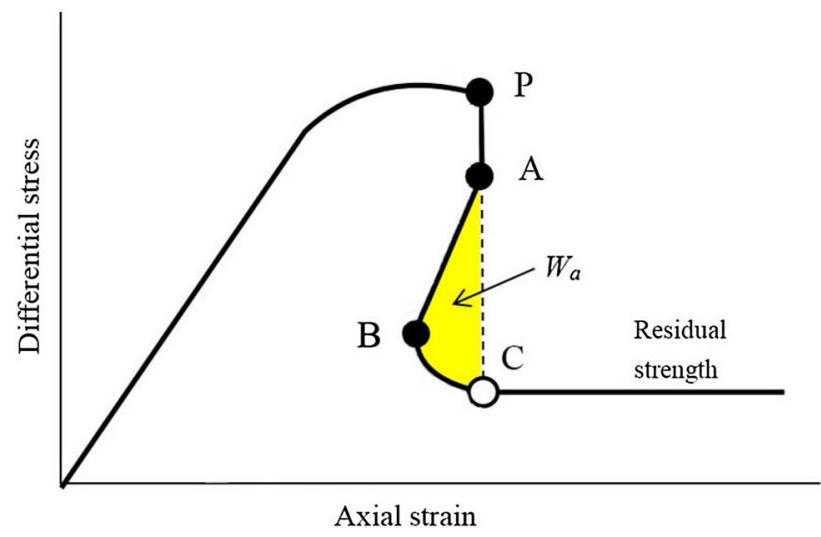

Fig. 4 Schematic stress-strain curve of Class II rock illustrating the excess energy $W_{\mathrm{a}}$ released from the rock after the peak stress

The energy, represented by the area bounded by ABCA and denoted as $W_{\mathrm{a}}$ in Fig. 4, is released from the rock specimen in this process of stress dropping. This excess energy would be converted to kinetic energy to eject rock. It is often released through reversing loops at different levels in the post-peak stage as shown in the stress-strain curves of the specimens tested under confining stresses 10 and $30 \mathrm{MPa}$ (Fig. 1b). The reason for the multi reversing loops may be the shear rupturing in the post-peak stage is a progressive and stepwise process. The excess energy would disappear when the confining stress is high enough beyond which the behaviour of the rock becomes Class I.

The stiffness of the test machine used for the tests is very high up to $15 \mathrm{GN} / \mathrm{m}$; with such stiffness, the energy released from the test machine frame is negligibly small. It was observed that rock specimens "exploded" (rock ejection) even though being tested on such a stiff machine when they were loaded uniaxially under load-controlled condition. The kinetic energy for the rock ejection must come from the rock specimen itself. It is believed that a part of the elastic strain energy stored in the rock specimen is dissipated to fracture rock and the rest excess energy is transformed to kinetic energy to eject rock. The excess energy is called intrinsic potential energy for strain burst in this paper. The excess energy is not zero only in Class II rock. It is illustrated on the stress-strain curve in Fig. 4.

The released excess energy $W_{\mathrm{a}}$ is an absolute measure for the intrinsic potential energy for strain burst in the rock. Another parameter to express the intensity of a burst event is the ejection velocity that is more explicit than the excess energy in the description of a burst event. The intrinsic ejection velocity, denoted as $V_{0}$, refers to the velocity of rock ejection in a burst event, which is purely caused by the excess energy $W_{\mathrm{a}}$ released from the ejected rock. Assuming that the excess energy is completely converted to kinetic energy to eject the rock specimen, we obtained the following expression for the ejection velocity:

$V_{0}=\sqrt{\frac{2}{\rho} W_{\mathrm{a}}}$

where $V_{0}$ is in $\mathrm{m} / \mathrm{s}, W_{\mathrm{a}}$ in $\mathrm{kJ} / \mathrm{m}^{3}$ and $\rho$ is the density of the rock in $\mathrm{kg} / \mathrm{m}^{3}$. Figure 5 shows the axial stress-strain curves of Kuru granite and Iddefjord granite under uniaxial compression. The excess energy $W_{\mathrm{a}}$ is marked in the two diagrams, which is $28.3 \mathrm{~kJ} / \mathrm{m}^{3}$ for the Kuru granite specimen and $3 \mathrm{~kJ} / \mathrm{m}^{3}$ for the Iddefjord granite. Assuming the density of the granites is $2700 \mathrm{~kg} / \mathrm{m}^{3}$, the intrinsic ejection velocities of the two granites are 4.6 and $1.5 \mathrm{~m} / \mathrm{s}$, respectively. It means that the Kuru granite would be more burst-prone than the Iddefjord granite.

\subsection{Effect of Confining Stress on the Fracture Angle}

\subsubsection{A Hypothesis for the Fracture Angle}

It is known that the angle of the shear rupture plane decreases with the confining stress, but the physics of the phenomenon is not clear to date. A hypothetical model for the formation of the shear rupture plane is proposed below. It has been observed that wing cracks are initiated at the tips of pre-existing micro cracks and they tend to propagate in the direction of the major principal stress $\sigma_{1}$, as shown in Fig. 6 

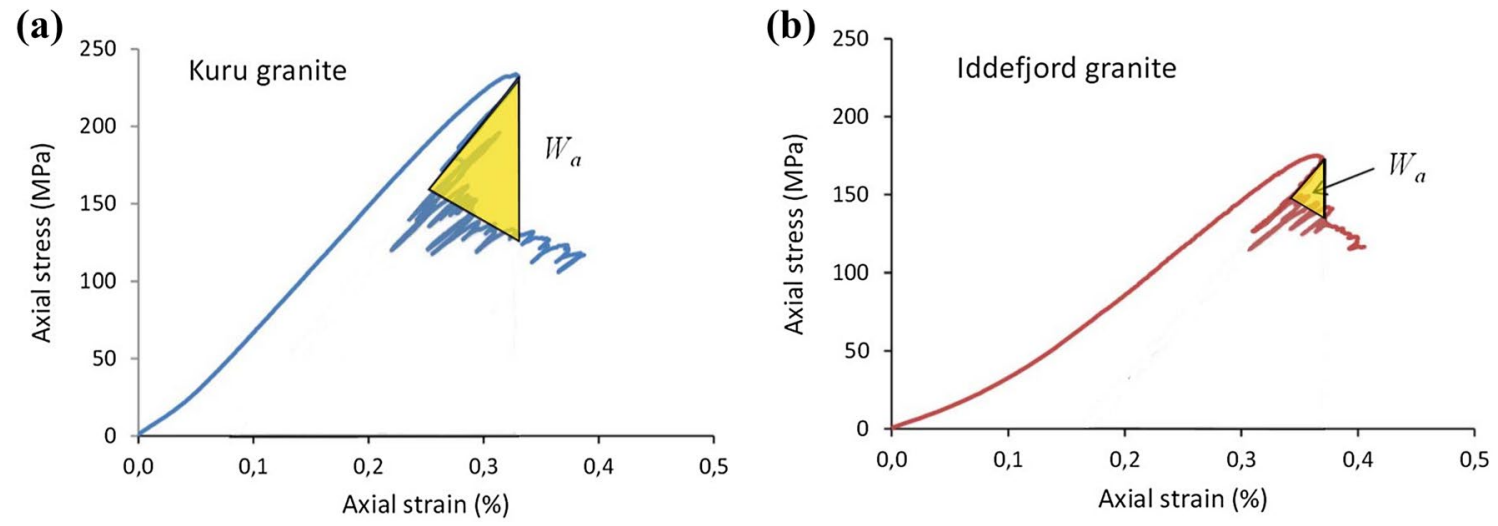

Fig. 5 The excess elastic energy $W_{\mathrm{a}}$ of $\mathbf{a}$ the Kuru granite (Tkalich et al. 2016) and $\mathbf{b}$ the Iddefjord granite under uniaxial compression

(a)

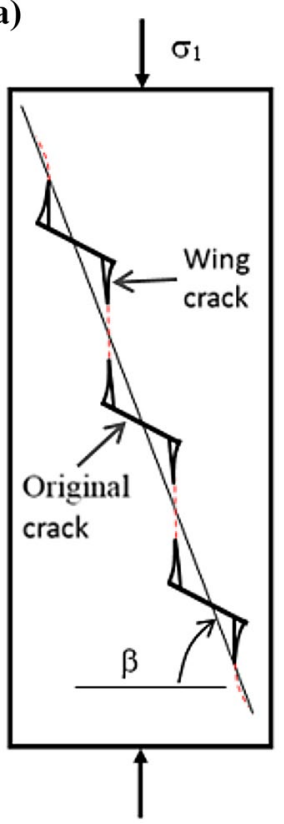

(b)

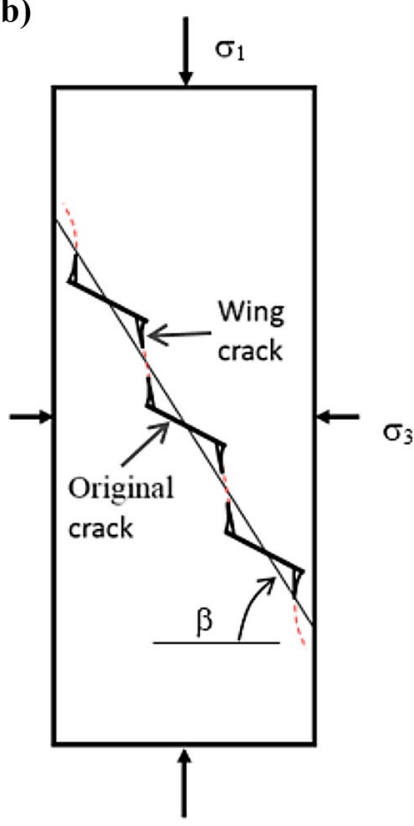

Fig. 6 A hypothetical model for the formation of the final shear fracture in rock under $\mathbf{a}$ uniaxial loading and $\mathbf{b}$ triaxial loading

(Horii and Nemat-Nasser 1986; Li and Nordlund 1993; Li et al. 1998; Bobet and Einstein 1998; Wong and Chau 1998; Wong et al. 2001; Yang et al. 2012). Tensile wing cracks would be initiated at the tips of the most shear-favourable micro cracks. Under uniaxial loading, the wing cracks could extend for a relatively long distance before they coalescence with sparsely spaced shear-favourable micro cracks to form a steep oblique fracture, as shown in Fig. 6a. Under triaxial loading, particularly when the confining stress $\sigma_{3}$ is high, the extension of wing cracks is limited by the confining stress and short wing cracks would be initiated on the pre-existing micro cracks. To the end, a less steep oblique fracture would be formed in the rock specimen by short wing cracks

and densely spaced pre-existing micro cracks, as shown in Fig. $6 \mathrm{~b}$. The reduction in the inclination angle of the final fracture plane may be due to the short wing crack extension and the activation of many shear-favourable pre-existing micro cracks in the triaxial loading condition.

The microscopic observations of the micro cracks in the shear bands by Bésuelle et al. (2000) showed that the micro cracks dominantly oriented in the direction of $\sigma_{1}$ at relatively low confining stress $30 \mathrm{MPa}$, but the cracks did not show preferential orientations at confining stress $50 \mathrm{MPa}$. The statistic results support the hypothesis that the wing cracks would be depressed at high confining stresses.

\subsubsection{The Quantitative Relationship Between the Fracture Angle and the Confining Stress}

In order to reduce the randomness of the test results, the fracture angles were also estimated on the failure envelope as illustrated in Fig. 7 (the angle in the figure is equal to $2 \beta$ ). The estimated fracture angles agree well with the measured angles shown in Fig. 2.

For the Fauske marble, the following relationship is obtained between the fracture angle and the confining stress by fitting the fracture angles estimated on the failure envelope:

$\beta=65.8 e^{-0.19 \sigma_{3} / \mathrm{UCS}}$,

where $\beta$ is in degrees and UCS is the uniaxial compressive strength of the rock.

Similarly, for the Iddefjord granite, the following relationship is obtained:

$\beta=75.9 e^{-0.36 \sigma_{3} / \mathrm{UCS}}$.

In general, the dependence of the fracture angle on the confining stress can be expressed as follows:

$\beta=\beta_{0} e^{-a \sigma_{3} / \mathrm{UCS}}$, 
(a)

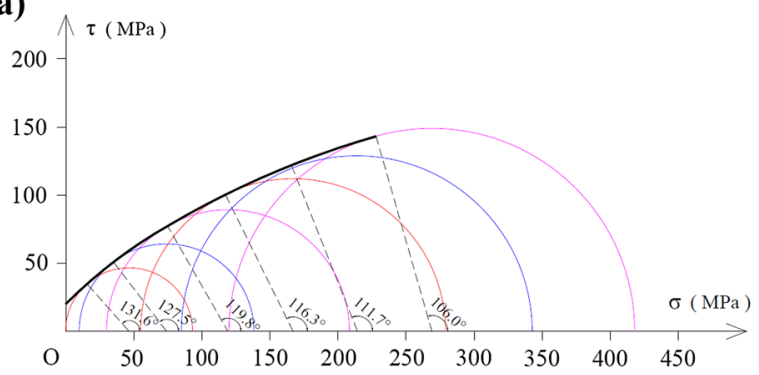

(b)

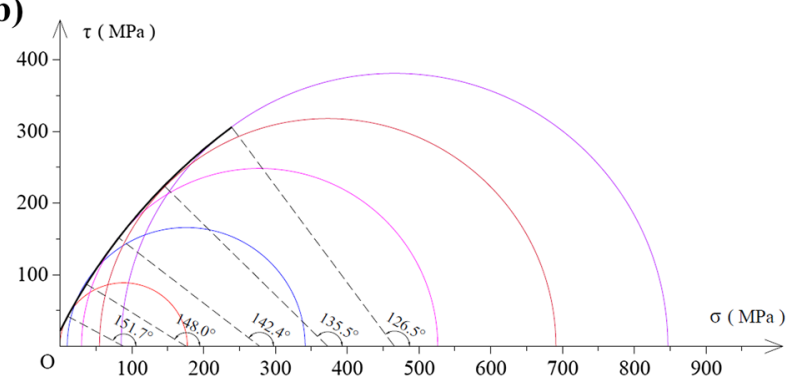

Fig. 7 A diagram illustrating the graphic method to determine the fracture angle on the failure envelope for a given confining stress: a marble; $\mathbf{b}$ granite

where $\beta_{0}$ stands for the fracture angle of the rock specimen under uniaxial loading $\left(\sigma_{3}=0\right)$. Letter $a$ is a material constant. The value of $a$ is 0.19 for the Fauske marble and 0.36 for the Iddefjord granite.

\section{Conclusions}

The increase in the ductility of the Class I rock Fauske marble with the confining stress is owing to the increase in damage in the rock. A damage index (DI) is proposed to describe the damage degree of Class I rock in the post-peak stage of a triaxial test. It is defined as the ratio of the fracture energy dissipated at a given strain in the post-peak stage of the triaxially tested specimen to the total fracture energy of the uniaxially tested specimen. The DI at the onset of shear faulting increases approximately linearly with the confining stress.

A portion elastic energy is released from the Class II rock after the differential stress reaches the ultimate value. The excess elastic energy is an absolute measure for the intensity of the intrinsic strain burst in the rock. It directly determines the intrinsic ejection velocity of the rock when a burst event occurs. The intrinsic ejection velocities of the Kuru granite and the Iddefjord granite are 4.6 and $1.5 \mathrm{~m} / \mathrm{s}$.

The fracture angle of rock is associated with the rock type and the confining stress. Based on the experimental data of the Fauske marble and the Iddefjord granite, the fracture angle is exponentially related to the ratio of the confining stress to the uniaxial compressive strength and a material constant. It is postulated that the decrease of the fracture angle with the confining stress is owing to the limitation of the confining stress to the extension of wing cracks. Shorter wing crack extensions under high confining stresses would results in smaller fracture angles.

Acknowledgements The authors would like to acknowledge the support of the National Natural Science Foundation of China (51578459), the Fundamental Research Funds for the Central Universities (2682015CX095) and the Norwegian University of Science and Technology (NTNU). The authors are grateful to Mr Gunnar Vistnes for his support during the tests in the Laboratory of Rock Mechanics at NTNU.

Open Access This article is distributed under the terms of the Creative Commons Attribution 4.0 International License (http://creativeco mmons.org/licenses/by/4.0/), which permits unrestricted use, distribution, and reproduction in any medium, provided you give appropriate credit to the original author(s) and the source, provide a link to the Creative Commons license, and indicate if changes were made.

\section{References}

Ai C, Zhang J, Li Y-W, Zeng J, Yang X-L, Wang J-G (2016) Estimation criteria for rock brittleness based on energy analysis during the rupturing process. Rock Mech Rock Eng 49:4681-4698

Alejano LR, Posada D, Rodríguez-Dono A (2009) Servo-controlled strength tests on moderately weathered granite. EUROCK 2009: rock engineering in difficult ground conditions: Soft Rock \& Karst. Catvat-Dubrovnik (Croatia). CRC. Taylord \& Francis Gr., London, pp 181-186

Bésuelle P, Desrues J, Raynaud S (2000) Experimental characterisation of the localisation phenomenon inside a Vosges sandstone in a triaxial cell. Int J Rock Mech Min Sci 37:1223-1237

Bobet A, Einstein HH (1998) Fracture coalescence in rock-type materials under uniaxial and biaxial compression. Int J Rock Mech Min Sci 35:863-888

Franklin JA (2007) Suggested methods for determining the strength of rock materials in triaxial compression. In: Ulusay R, Hudson JA (eds) The complete ISRM suggested methods for rock characterization, testing and monitoring: 1974-2006. The ISRM Turkish National Group, Ankara, pp 157-164

Gowd TN, Rummel F (1980) Effect of confining pressure on the fracture behaviour of a porous rock. Int J Rock Mech Min Sci Geomech Abstr 17:225-229

Hauquin T, Gunzburger Y, Deck O (2018) Predicting pillar burst by an explicit modelling of kinetic energy. Int J Rock Mech Min Sci 107:159-171

Hoek E, Brown ET (1980) Empirical strength criterion for rock masses. J Geotech Eng Div ASCE 106:1013-1040

Hoek E, Brown ET (1982) Underground rock excavation. Institution of Mining and Metallurgy, London

Horii H, Nemat-Nasser S (1986) Brittle failure in compression: splitting, faulting and brittle-ductile transition. Philos Trans R Soc Lond A 319:337-374

Huang D, Li Y (2014) Conversion of strain energy in triaxial unloading tests on marble. Int J Rock Mech Min Sci 66:160-168

Li C, Nordlund E (1993) Deformation of brittle rocks under compression-with particular reference to microcracks. Mech Mater 15:223-239 
Li C, Prikryl R, Nordlund E (1998) The stress-strain behaviour of rock material related to fracture under compression. Eng Geol 49(3/4):293-302

Mogi K (1966) Some precise measurements of fracture stress of rocks under uniform compressive stress. Rock Mech Eng Geol 4:41-55

Mogi K (1971) Fracture and flow of rocks under high triaxial compression. J Geophys Res 76:1255-1269

Paterson MS (1978) Experimental rock deformation: the brittle field. Springer, Berlin

Scott TE, Nielsen KC (1991) The effects of porosity on the brittle-ductile transition in sandstones. J Geophys Res Solid Earth 96:405-414

Tarasov B, Potvin Y (2013) Universal criteria for rock brittleness estimation under triaxial compression. Int J Rock Mech Min Sci 59:57-69

Tarasov BG, Stacey TR (2017) Features of the energy balance and fragmentation mechanisms at spontaneous failure of Class I and Class II rocks. Rock Mech Rock Eng 50(10):2563-2584

Tkalich D, Fourmeau M, Kane A, Li CC, Cailletaud G (2016) Experimental and numerical study of Kuru granite under confined compression and indentation. Int J Rock Mech Min Sci 87:55-68

Walton G, Arzúa J, Alejano LR, Diederichs M (2015) A lab-testing based study on the strength, deformability, and dilatancy of carbonate rocks at low confinement. Rock Mecha Rock Eng 48:941-958

Wawersik WR, Fairhurst C (1970) A study of brittle rock fracture in laboratory compression experiments. Int J Rock Mech Min Sci Geomech Abstr 7:561-575

Wong RHC, Chau KT (1998) Crack coalescence in a rock-like material containing two cracks. Int J Rock Mech Min Sci 35:147-164

Wong RHC, Chau KT, Tang CA, Lin P (2001) Analysis of crack coalescence in rock-like materials containing three flaws-part I: experimental approach. Int J Rock Mech Min Sci 38:909-924

Yang S-Q, Jing H-W, Wang S-Y (2012) Experimental investigation on the strength, deformability, failure behavior and acoustic emission locations of red sandstone under triaxial compression. Rock Mech Rock Eng 45(4):583-606

Yao M, Rong G, Zhou C, Peng J (2016) Effects of thermal damage and confining pressure on the mechanical properties of coarse marble. Rock Mech Rock Eng 49:2043-2054

Publisher's Note Springer Nature remains neutral with regard to jurisdictional claims in published maps and institutional affiliations. 